\title{
Inhalt
}

\section{Alfred Bellebaum}

Einleitung

\section{Jan Assmann}

Glück und Weisheit im Alten Ägypten

Diskussion: Klaus Barheier

\section{Bernhard Lang}

Religion und menschliche Glückserfahrung:

Zur alttestamentlichen Theorie des Glücks

Diskussion: Gerhard Schmied

\section{Giuseppe Veltri}

Konzepte des "Glücks" im antiken Judentum

\section{Heinrich von Stietencron}

Das Glück und die Schatten der Vergänglichkeit. Religiös-philosophische Konzeptualisierungen von Glück im alten Indien 
Wolfgang Bauer

Utopismus und Wirklichkeitssinn im alten und im neuen China

Diskussion: Gerhard Vowinckel

220

\section{Klaus Antoni}

Fuku und sachi - die religiöse Konzeption des

Glücks in der japanischen Kultur

Diskussion: Rainer Waßner

266

Personenregister

Sachregister

275

Die Mitwirkenden

280 